\title{
Autocad Learning Video Development Using Open Broadcaster Software Application
}

\author{
Annisa' Carina $^{1^{*}} \quad$ Sulistianingsih $^{2}$ \\ STT STIKMA Internasional, Jl. Simpang Sulfat Utara No. 20 Malang, Indonesia
}

\begin{abstract}
Autocad is one of the most important applications, especially in engineering, including architecture. However, there are no specific courses that teach design using Autocad. Thus causing some problems found in the implementation of teaching and learning. First, there are not a few students who do not understand the functions and uses of Autocad itself, thus making lecturers have to provide basic material about Autocad outside of the subjects that should be delivered. Second, the limitations of students who have personal computers, so that students are less than optimal in independent learning regarding the functions and uses of Autocad and rely more on learning in the computer laboratory. Third, the low interest of students in reading books related to Autocad knowledge. For this reason, researchers will make learning videos for the basics of Autocad, besides that with this learning video, it will make it easier for lecturers to assign courses according to the subject matter but require Autocad so that the ability of students who still do not understand the functions and uses of Autocad are not constrained. In this study, the learning video was validated by DOsen Aexperts who will validate the overall content of the product in the form of learning videos. In addition to validation sheets, data collection was also carried out through questionnaires or questionnaires distributed to students. This questionnaire instrument uses a Likert scale. From the research validation process, it shows that the results of the material test have a value of $68.75 \%$ which are categorized as good enough criteria, the media test has a value of $90.38 \%$ which is categorized in very good criteria and the test to students has a value of $79.54 \%$ which is categorized in very good criteria, so the Autocad learning video is feasible to be used in the learning process..
\end{abstract}

Keywords: learning videos, Autocad

DOI: $10.7176 / \mathrm{JEP} / 12-27-05$

Publication date:September $30^{\text {th }} 2021$

\section{Introduction}

The development of technology in the modern era is now felt, both in the fields of education, industry, and transportation. It's different from the old days where people did it manually. One example is the field of architecture and contractors. In the past, they used to draw a project using the manual method, namely with a drawing table and tracing paper. But in this modern era, there are many software for $2 \mathrm{D}$ and $3 \mathrm{D}$ drawing, one example is Autocad. Various applications are used to support work results in the field of architecture and in the field of contractors.

With the presence of software such as Autocad, we have no difficulty in drawing 2D and 3D.

According to Haria (2006) Autocadis a drawing program capable of producing high-precision images, both 2D and 3D. The Autocad family of products, as a whole, is the most widely used CAD software in the world. In the world of education, Autocad is one of the most important applications, whether in the fields of civil engineering, architecture, mechanical engineering or other applied engineering sciences, you will be very familiar with this application. Because this application is most widely used in drawing in several courses in the field of science.

Reported from Witanto's research (2018) that there are several factors that cause the condition of low interest in reading, one of which is the development of information technology so that it shifts people's interest in reading book activities. For this reason, researchers will make interactive videos related to basic Autocad learning, so that students can learn by using smartphones. There are several advantages of video tutorials according to Agustiningsih (2015) that learning is more interesting so that it can increase learning motivation and increase students' understanding of learning materials.

The use of communicative media and learning resources according to the era in learning is one way that can be used to support the level of student understanding. According to Budiningsih (2004) the ability of students to learn new information related to the material that has been obtained will make it easier for students to learn the learning material.Learning resources can be obtained from all objects that are around students who are studying, one of which can be obtained from learning video media used in the learning process. Hinic et.al (in Daryanto, 2012) defines media as an intermediary or introduction to the occurrence of communication from the sender to the receiver. Based on this definition, learning media is a means of intermediary in the learning process.

The purpose of this research is to produce an Autocad learning video that can help students' basic understanding of the functions and uses of Autocad. Dimyati (2009) suggests that learning can be done from video, television, radio, newspapers so that it can facilitate learning. For this reason, researchers will make one 
of them, namely Autocad learning videos, besides that this learning video will make it easier for Lecturers to carry out course assignments according to the course material but require Autocad so that the ability of students who still do not understand the functions and uses of Autocad are not constrained.

\section{Method}

This research is included in development research. Development research is also called Research and Development (R\&D). R\&D is a research method used to produce a product. Sugiyono (2014) states that research and development (R\&D) methods are research methods used to produce certain products, and test the effectiveness of these products. So the purpose of the research and development in the field of education and learning, namely to improve and develop the quality of effective learning.

According to Syaodih (1996), learning media are everything that can be used to convey messages or lesson content, stimulate students' thoughts, feelings, concerns, and abilities so that they can encourage the teaching and learning process. Meanwhile, according to Sudjana (2007), teaching media is in the methodological component, as one of the learning environments adopted by the teacher. Sources of learning materials can be formed more effectively and efficiently on CDs or cassettes. In this form, it is believed that the material will be more interesting to study because with animation, audio and visual techniques, the learning material will be clearer and more concrete. With the media in the form of learning videos, it will stimulate students to learn independently outside of classroom learning. According to Khaidir (2016) teaching materials are independent, meaning that students can learn independently because these teaching materials have a systematic structure and sequence, namely: a) explaining the instructional objectives to be achieved; b) motivate students to learn; c) accommodate student learning difficulties; d) provide training opportunities for students, e) provide summaries; and f) student oriented individually learner oriented).

The development model according to Alessi \& Trollip (2001), namely with the following steps:

1.1 Planning

1.1.1 Determine needs and goals

Needs and goals include what students will know or be able to do after completing learning.

\subsubsection{Gather resources}

The sources referred to are reference books, original source materials, films and knowledge from other people in the field that supports the making of videos.

1.1.3 Generating ideas

This stage is a brainstorming to generate creative ideas for development.

1.2 Design

\subsubsection{Making flowcharts}

Making flowcharts to facilitate the running of the program, especially the implementation operations on the computer.

\subsubsection{Create a written storyboard}

This stage includes planning (drafting), writing and revising the storyboard along with its appearance, animation, graphics, and music, then validating it.

\subsubsection{Preparing scripts}

This stage includes planning narration, instruments, animation on the video.

\subsection{Development}

\subsubsection{Producing video and audio}

In this stage the creation of displays, animations, graphics, music, narration, and instruments that can support development.

1.3.2 Preparing supporting components

1.3.3 Programming material

This stage is the stage of combining all the material developed, including the application program that will be used.

1.3.4 Evaluate and review (test and validate)

Based on this opinion, the research procedure for developing learning videos that the researcher uses refers to the development procedure of Allesi and Trollip (2001), namely: (1) planning: determining needs and objectives, collecting sources, and generating ideas. (2) design: making flowcharts, making storyboards, and preparing scripts. (3) development: producing video and audio, programming materials, preparing supporting components, evaluating and revising.

The following is the flow of the stages of developing learning videos in this study:. 


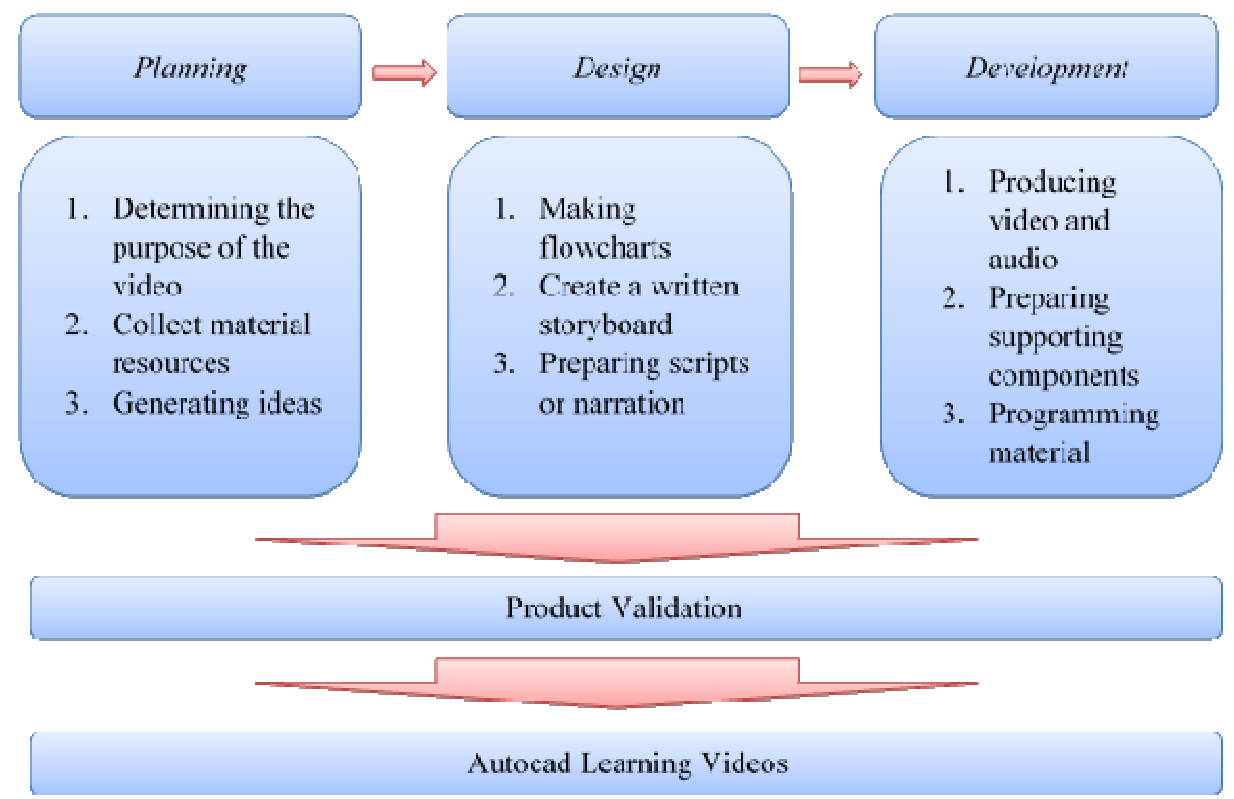

\section{Analysis}

According to Riyana (2007) learning video media is media that presents audio and visuals that contain good learning messages that contain concepts, principles, procedures, theory of knowledge application to help understanding of a learning material. Autocad learning videos before being tested need to be validated by experts, namely material experts and media experts. Expert validation is useful for finding out and correcting errors in the learning video that will be developed. After being validated by material experts and media experts, further trials were carried out on students.

Expert testing or validation is carried out with expert respondents to assess the initial product and provide input for improvement. The data from the material expert and media expert tests are the initial data used to view and revise the product before conducting a small-scale trial, while the data in the form of a questionnaire is calculated to determine the results of media feasibility according to material experts and media experts. The data in the questionnaire is first converted into numbers and then entered into certain categories.

Validation by material experts includes assessment of preliminary, content, evaluation and closing aspects. The percentage formula used to calculate each indicator is as follows:

$$
\begin{array}{ll}
\mathrm{K} & =\mathrm{F} /\left(\mathrm{N} * \mathrm{I}^{*} \mathrm{R}\right) * 100 \% \\
\mathrm{~K} & =\text { Percentage } \\
\mathrm{F} & =\text { Number of respondents' answers } \\
\mathrm{N} & =\text { Highest score in the questionnaire } \\
\mathrm{I} & =\text { Number of questions in the questionnaire } \\
\mathrm{R} & =\text { Quantity respondents, (Riduwan, 2005:6). }
\end{array}
$$

Each variable has an interpretation that is adjusted to the scale used. After performing the percentage calculation process, the results are entered into the analysis of the achievement criteria for each variable. The analysis used is the percentage technique according to Akbar and Sriwijaya (2010:213) as shown in Table 1.

Table 1. Ideal Score Category

\begin{tabular}{|c|c|}
\hline Score Range (\%) & Category \\
\hline $75.01-100.00$ & Very good \\
$50.01-75.00$ & Pretty good \\
$25.01-50.00$ & Not good \\
$00.00-25.00$ & Not good \\
\hline
\end{tabular}

3.1 Material expert validation test

The results of material validation can be seen from the calculations below:

$\mathrm{K}=(33 / 48) * 100 \%$

$$
=68,75 \%
$$

Based on the results of the material validation test, a score of $68.75 \%$ is obtained which falls into the fairly good category. This means that the Autocad learning videos made by researchers are quite good.

3.2 Media expert validation test

The results of media validation can be seen from the calculations below:

$\mathrm{K}=(47 / 52)^{*} 100 \%$ 


$$
=90,38 \%
$$

Based on the results of the media validation test, a value of $90.38 \%$ was obtained which was included in the very good category. This means that the Autocad learning videos made by researchers are good.

3.3 Media testing for students

The results of media validation can be seen from the calculations below:

$$
\mathrm{K}=(140 / 76) * 100 \%
$$

$$
=79,54 \%
$$

Based on the results of the Autocad learning video trial for students, a score of $90.38 \%$ was obtained which was in the very good category. This means that the learning videos made by researchers are good

Based on the analysis, it can be seen that the results of the material test have a value of $68.75 \%$ which is categorized as good enough, the media test has a value of $90.38 \%$ which is categorized as very good and the test to students has a value of $79.54 \%$ which is categorized in very good criteria, so the Autocad learning video is feasible to be used in the learning process.

\section{Conclusion}

Based on the results of research conducted by researchers, it can be concluded:

4.1 At stage Planning (planning) results in an analysis of the learning media needs needed by students of the Architecture Study Program regarding Autocad learning to support courses in the Architecture Study Program.

4.2 At the Design (goal) stage, an audiovisual-based learning media design is produced. The design starts from analyzing the needs of students of the Architecture Study Program, the process of making Autocad learning using applicationsOpen Broadcaster Software or commonly called OBS, then do video editing.

4.3 The product of this learning media development is a learning video that displays learning the basics of Autocad. This video is in .mp4 format with a size of $240 \mathrm{MB}$, and has been tested to be played on Windows devices and on Android-based smartphone devices.

4.4 Based on the feasibility test, this learning video has a score of $68.75 \%$ which is categorized in the fairly good criteria, the media test has a value of $90.38 \%$ which is categorized as very good criteria and the test to students has a value of $79.54 \%$ which is categorized in the very good criteria. good, so this video for learning the basics of Autocad is suitable for use in the learning process.

\section{References}

Agustiningsih. (2015). "Video as an alternative learning media in order to support the successful implementation of the 2013 curriculum in elementary schools". Radiant Journal, Vol. 4, No. 1, pp. 55-68.

Akbar, S., and Sriwijaya, H. (2010). "Curriculum Development and Social Science Learning”. Malang: Cipta Medika.

Alessi \& Trollip. Stephen M. Alessi \& Stanley R. Trollip. (2001). "Multimedia for Learning Methods And Development". Massachusetts: Alin and Bacon

Budiningsih, Asri. (2004). "Learning and Learning”. Jakarta: PT. RINEKA COPYRIGHT.

Academic Manual 2014. Malang: STT STIKMA International.

Daryanto. (2012). "Learning Media". Bandung: PT. Prosperous Conscience Tutorial Facility.

Dimyati, Mujiono. (2009). "Learning and Learning". Jakarta: PT. RINEKA COPYRIGHT.

Haria Aria, Soma. (2006). "Proficient in Using Autocad 2D Release 2006". Jakarta: Elex Media Komputindo.

Khaidir, Christina. (2016). "Development of -Based Numerical Method Textbooks

Constructivism at IAIN Batusangkar". Ta'dib, Vol. 19, No. 1, 67-82.

Riduwan. (2005). "Formulas and Data in Statistical Analysis". Jakarta: Alpha Beta.

Riyana, Cheppy. (2007). "Guidelines for Video Media Development”. Jakarta: P3AI UPI

Sanjaya, Wina. (2008). "Planning and design of learning systems". Jakarta: Kencana Prenadamedia Group.

Sudjana, Nana. (2007). "Teaching Technology”. Bandung: Sinar Baru Algesindo.

Sugiyono. (2014). "Research Educational Approaches to Quantitative, Qualitative and R\&D". Bandung: Alphabeta.

Syaodih, Nana. (1996). "Teaching Planning”. Jakarta: Rineka Cipta.

Witanto, Jajam. (2018). "Very Low Reading Interest. Stya Wacana Christian University Salatiga": Thesis of the Faculty of Teacher Training and Education. 